Egyptian Journal of Aquatic Biology \& Fisheries

Zoology Department, Faculty of Science,

Ain Shams University, Cairo, Egypt.

ISSN $1110-6131$

Vol. 25(2): $677-687$ (2021)

www.ejabf.journals.ekb.eg

\title{
Growth Pattern, Diet and Tropical Niche Breadth of the Nile Silver Catfish, Schilbe mystus (Linne 1758) in Asejire Lake, Southwestern, Nigeria
}

\section{Kazeem Kareem $^{1}$, Nurudeen Olanrewaju ${ }^{2, *}$, and Bunmi Igbaro ${ }^{1}$}

${ }^{1}$ Department of Aquaculture and Fisheries Management, University of Ibadan, Nigeria

${ }^{2}$ Federal College of Freshwater Fisheries Technology, P.M.B 1060, Maiduguri, Nigeria

*Corresponding Author: arogidigbaonline@yahoo.com

\section{ARTICLE INFO}

Article History:

Received: Oct. 14, 2020

Accepted: March 22, 2021

Online: April 26, 2021

Keywords:

Nile Silver Catfish,

Schilbe mystus,

Growth,

Feeding habit,

Niche breadth,

Asejire Lake.

\begin{abstract}
Schilbe mystus is a valued endemic fish species in the Nigerian freshwater, with great potential for culture. Nevertheless, controlled rearing is currently rare due to the lack of knowledge on its food and feeding habits besides other factors. Therefore, growth, food and feeding habits of $S$. mystus in Asejire Lake were investigated for six months (July to December, 2018). A total of 105 specimens $(86.00 \pm 14.30 \mathrm{~g})$ were collected from fishers. Samples were sexed and grouped according to sizes. Length-weight relationships (LWR) and condition factor were assessed using standard procedures. Gut contents and niche breadth $(\mathrm{Bi})$ were analyzed and quantified using a standard approach. In addition, qualitative and quantitative variations in diet were determined according to sex, size and seasons. Data were analyzed using descriptive statistics, chi-square and multiple linear regressions. The LWR indicated negative allometry growth with ' $b$ ' value of 2.87 and coefficient of determination $\left(\mathrm{R}^{2}\right)$ of 0.85 . The condition factor of $S$. mystus was $1.32 \pm 0.26$,

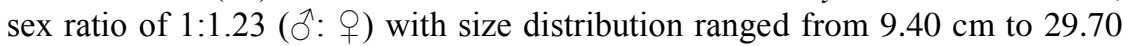
$\mathrm{cm}$. Dietary analysis showed that $S$. mystus is a europhagous feeder and a benthic omnivore. Insects, crustaceans and planktons constituted the major food items. Furthermore, significant differences in feeding habits of S. mystus occurred according to sex, size and seasons. The Bi value was high (2.15), indicating a trophic generalist. Hence, this research was conducted to provide key information necessary for formulation of artificial diet for S. mystus under captivity.
\end{abstract}

\section{INTRODUCTION}

The development of aquaculture in Nigeria has been steady in the last three decades. It increased considerably from a small base of 16,119 in 1995 to 307,000 metric tons in 2016 (FDF, 2011; FAO, 2018). Aquaculture continues to show a promise for a more rapid expansion to fill the gap created by the decline in capture fisheries. However, growth in aquaculture industry in Nigeria is mostly dominated by catfish farming, Clarias gariepinus (Williams et al., 2007), despite over 300 indigenous, cultivable freshwater fish species (Olaosebikan \& Raji, 2013). The domination of $C$. gariepinus requires more attention because the consumer's choice is unduly limited. Kpogue et al. (2012) stressed that the development in aquaculture could only be sustainably achieved through the farming of arrays 
of endemic species in inland waters. Hence, species such as Schilbe mystus needs to be considered as aquaculture candidate.

The freshwater Nile silver schilbeid catfish, Schilbe mystus, (Order: Siluriformes, Family: Schilbeidae) is one of the most dominant fish species in Nigeria inland waters. It prefers standing or slowly flowing open water of lakes, ponds, rivers, and shallow swamps where vegetation is present (Zengeya, 2016). It can grow up to a length of $70 \mathrm{~cm}$ and a weight of $250 \mathrm{~g}$ (Azeroual et al., 2010), with good quality food fish of white and very tasty flesh serving as delicacy for many low-income earners (Reed $\boldsymbol{e t}$ al., 1967), especially in riverine communities. Schilbe mystus is a column and surface feeders; feeding on fish, insects, crustaceans, ostracods, snails, seeds, leaves, roots, diatoms, algae, and fruit (Omondi \& Ogari, 1994; Ayoade et al., 2008; Zengeya, 2014).

According to Kareem et al. (2019), the emanating need to culture fishes for protein consumption for the teeming rapidly growing populations in the developing countries have made it necessary to intensify studies on the food and feeding habits of the African freshwater fishes. Moreover, it is noted that the successful domestication of any fish species demands a thorough knowledge of its diet and dietary habits. The knowledge of food and feeding habits enables farmers to have clear understanding of the fish's dietary requirements to formulate appropriate feeds under culture (Malami et al., 2004). As pointed out by Fagade (1978), the analysis of the stomach content of fish is a useful guide to form artificial diets in fish culture. Further, the food and feeding habits of fish species may differ in time, space as well as different stages of growth (Hardy, 1924) and this would, in turn, pinpoint the importance of detailed study of food and feeding habits.

Many studies have been carried out on the food and feeding habits of this commercially important fish species. These include the works of Omodi and Ogari (1994), Fawole (2002), Oso et al. (2006), Ayoade et al. (2008), Malami and Magawata (2010). However, a review of literature showed paucity of information on the food and feeding habits of $S$. mystus from Asejire Lake in the last decade. Therefore, there is a need to investigate the food and feeding habits of $S$. mystus to enhance its aquaculture potentials.

\section{MATERIALS AND METHODS}

\section{Study area}

Asejire Lake, with a surface area of $24 \mathrm{~km}^{2}$, is located in Egbeda local government, Oyo State, Nigeria (Fig. 1). The main body of the lake lies about $30 \mathrm{~km}$ east of Ibadan, between latitudes $7^{\circ} 21^{\prime} 30^{\prime \prime}-7^{\circ} 21^{\prime} 50^{\prime \prime} \mathrm{N}$ and longitudes $4^{\circ} 07^{\prime} 30^{\prime \prime}-4^{\circ} 08^{\prime} 10^{\prime \prime} \mathrm{E}$, at an altitude of $137 \mathrm{~m}$ above sea level. It was formed by a dam constructed across River Oshun in 1960. The lake is Y-shaped with two unequal arms: the long arm is River Osun, while the short is River Oba (Ayodele, 1979). The lake is fed by two rivers, River Osun and its main tributary River Oba. Its entire length is $19.5 \mathrm{~km}$, with catchment and impounded area of 7,800 $\mathrm{km}^{2}$ and 2,342 hectares, respectively. It has a normal pool elevation (water level) of $150 \mathrm{~m}$, and maximum flood elevation of $152.4 \mathrm{~m}$ with gross storage of 7,403 million liters. It has gross storage capacity of 7,403.4 million liters per day, while its discharge capacity is 136.26 
million liters per day (Ayodele, 1979) with maximum water capacity of about $675 \mathrm{~m}^{3}$. The reservoir sustains a thriving artisanal fisheries industry, and serves as a source of water for domestic and industrial use. It is rich in diverse fish resources, and located in a tropical derived savannah climate with two clearly marked wet seasons between April and September, and dry seasons between November and March. Remarkably, fishing activity is prominent in the reservoir.

\section{Sample collection}

Samples $(n=105)$ were collected using cast nets and surface gill nets over a period of 6 months; from July to September 2018 (wet season) and October to December 2018 (dry season). Samples were anaesthetized at the collection site, preserved in 5\% neutral formalin and transported to the Wet Laboratory of Aquaculture and Fisheries Management Department, University of Ibadan for further examination. Fish caught were identified according to Olaosebikan and Raji, (2013).

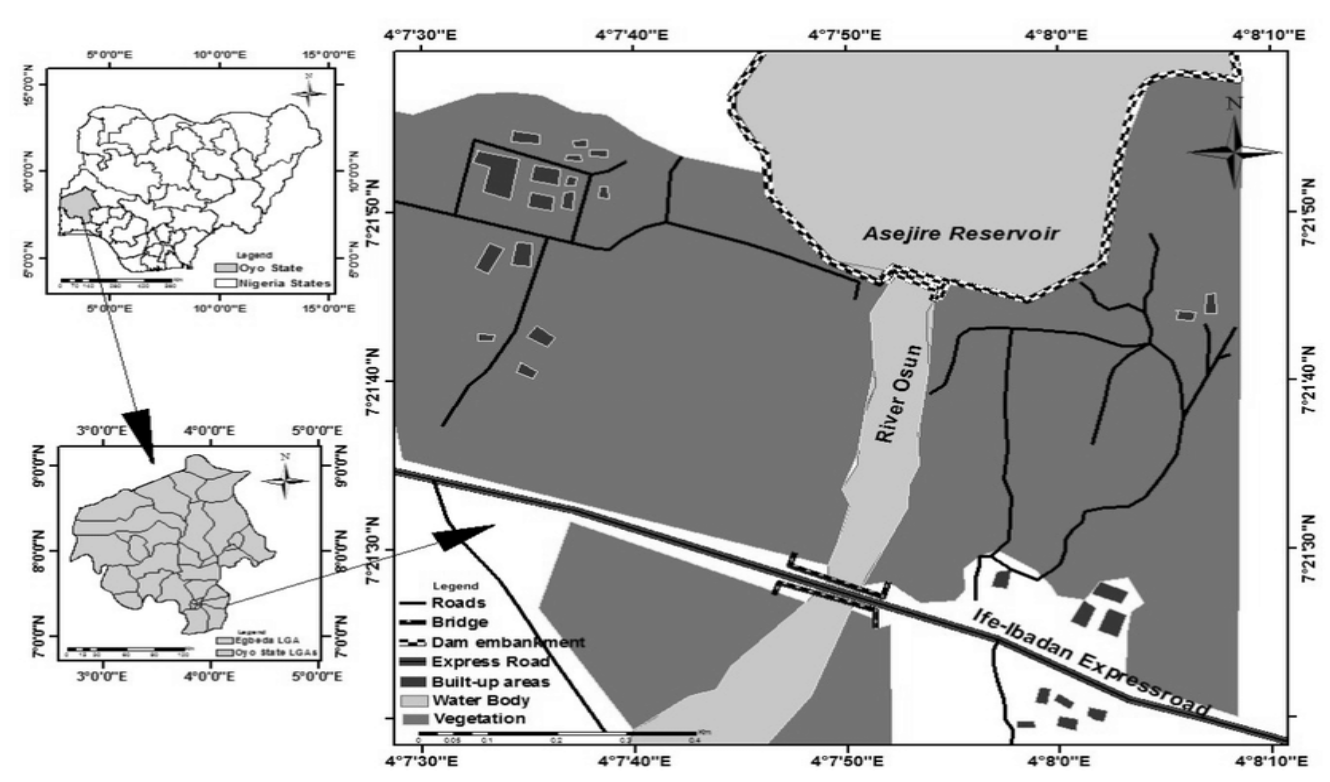

Fig. 1. A map of Asejire Lake, Oyo State, Nigeria

\section{Morphometric and laboratory analysis}

In the laboratory, samples were measured for a standard length to the nearest $0.1 \mathrm{~cm}$ on a wooden measuring board $(60.0 \mathrm{~cm})$. Body weight was recorded with a precision balance (OHAUS Model CT 6000) to the nearest $0.1 \mathrm{~g}$. The samples examined were divided into small-sized group (9.0 to $15.2 \mathrm{~cm})$ and large-sized group $(15.3$ to $29.7 \mathrm{~cm})$ to establish variation in food items. Sexes were determined based on the possession of a genital papilla by the male, and binocular dissecting microscope was used for some small specimens. 


\section{Length-weight relationship (LWR) and condition factor}

The parameters for the LWR models were estimated by linear regression on logtransformed data, using the statistical package for social sciences. The LWR model is a function of length $(\mathrm{L}), \mathbf{W}=\mathbf{a} \mathbf{L}^{\mathbf{b}}$; which was transformed to logarithmic modification according to the following equation: $\log \mathbf{W}=\mathbf{a} \pm \mathbf{b} \log \mathbf{L}$. Fulton's condition factor (K) was calculated based on LeCren (1951) using the equation of $\mathrm{K}=100 \mathrm{~W} / \mathrm{L}^{3}$. Where, $\mathrm{K}=$ condition factor; $\mathrm{W}=$ weight of fish $(\mathrm{g})$ and $\mathrm{L}=$ Length of fish $(\mathrm{cm})$. The correlation coefficient $\left(\mathrm{R}^{2}\right)$ was estimated to determine the degree of relationship between the length and weight of the samples.

\section{Stomach content analysis}

The fish was dissected and the gut was taken out for dietary analysis. The food composition in each gut was determined using a points and occurrence method as described by Hyslop (1980). Each category of food was sorted out and points were awarded for each food item. Thus, the total points allotted in a food category in all samples were summed and expressed as the percentage of the total points. Combining percentage of occurrence and points, the index of preponderance (I) was calculated following Natarajan and Jhingran (1961).

$$
\mathbf{I}=\frac{V i O i}{\sum V i O i} x 100
$$

Where: $\mathrm{I}$ is the index of preponderance of the food item, $\mathrm{V}_{\mathrm{i}}$ is the percentage of volume index of the item, and $\mathrm{O}_{\mathrm{i}}$ is the percentage of occurrence index of the item.

\section{Trophic niche breadth}

Diet breadth (Bi), which is a measure of the food spectrum, is determined following Hulbert (1978) formula:

$$
\mathrm{Bi}=\frac{1}{\sum P i 2}
$$

Where, $\mathbf{B i}$ is the trophic niche breadth and $\mathbf{P}_{\mathbf{i}}$ is the numeric proportion of food item $\mathbf{i}$ in the diet.

\section{Statistical analysis}

Data obtained were analyzed using descriptive statistics, chi-square and multiple linear regressions in statistical package for social sciences (SPSS for Windows version 20).

\section{RESULTS}

\section{Growth pattern and condition factor}

The sample size and sex distribution of $S$. mystus examined are shown in Table (1). A total of 105 fish samples composed of 47 (44.76\%) males and $58(52.24 \%)$ females were collected during the study period. The sex ratio (male: female) for sampled population in 
Asejire Lake was $1.0 \delta^{\lambda}: 1.23 q$, which did not show departure from the expected 1:1 rate $\left(\chi^{2}\right.$ $=3.65 ; \mathrm{p}>0.05$ ).

The specimens weighed between $17.60 \mathrm{~g}$ and $275.20 \mathrm{~g}$, with an average of $86.00 \pm 14.30 \mathrm{~g}$. While the standard length ranged between $9.40 \mathrm{~cm}$ and $29.70 \mathrm{~cm}$, with an average of $19.30 \pm 3.50 \mathrm{~cm}$. The equation of length-weight relationship, as obtained, was: Log $\mathrm{W}=-1.74+2.87$ Log SL (Fig. 2). The regression analysis revealed a high significant difference $(p<0.05)$ with coefficient of determination $\left(\mathrm{R}^{2}\right)$ of 0.85 . However, the mean condition factor was $1.32 \pm 0.26$.

Table 1: Length-weight distribution and condition factor of S. mystus, captured from Asejire Lake, Oyo State, Nigeria.

\begin{tabular}{lccccc}
\hline \multicolumn{1}{c}{ Parameters } & Mean \pm SD & Range & p-value & $\mathbf{R}^{2}$ & $\begin{array}{c}\text { Condition factor } \\
(\mathbf{K})\end{array}$ \\
\hline Standard length $(\mathrm{cm})$ & $19.30 \pm 3.50$ & $9.40-29.70$ & $<0.05$ & 0.8 & $1.32 \pm 0.26$ \\
Body weight $(\mathrm{g})$ & $86.40 \pm 14.30$ & $17.60-275.20$ & & 5 & \\
\hline
\end{tabular}

Where SD is standard deviation and $\mathrm{R}^{2}$ is correlation coefficient.

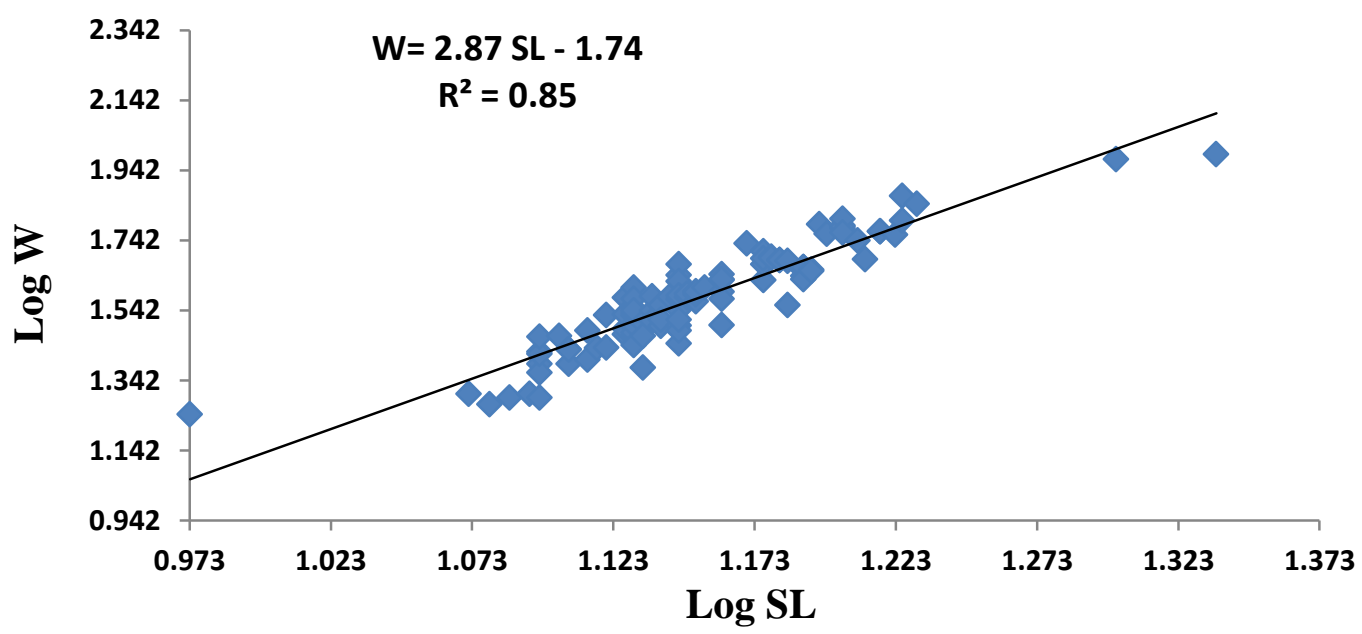

Fig. 2: Length-weight relationship of Schilbe mystus in Asejire Lake, Oyo State, Nigeria.

\section{Food items in relation to size, season and sex}

Major food items of S. mystus in relation to size, season and sex are presented in Table (2). The predominant food items in both small-sized $(9.0$ to $15.2 \mathrm{~cm})$ and large-sized $(15.3$ to $29.7 \mathrm{~cm})$ groups are insects, crustaceans, plankton and macrophytes. Small-sized group however, had high occurrence of insect (55.2\%) and crustacean (26.0\%); while plankton $(26.0 \%)$ and macrophyte $(13.1 \%)$ were more pronounced in large-sized group. Seasonally, the most common food items identified during dry season were plankton $(55.0 \%)$, macrophyte (4.0\%) and Charcoal (1.5\%). Whereas in wet season, crustacean (28.0), insects $(58 \%)$ and mollusc $(1.0 \%)$ were frequent. As shown in Table (2), the occurrence of crustacean $(22.0 \%)$, insect $(58.2 \%)$, mollusc $(1.8 \%)$, macrophyte $(5.4 \%)$ and charcoal (1.8 
$\%)$ were significantly $(p<0.05)$ higher in male while only plankton $(62.0 \%)$ predominated in female. There was a significant difference among the occurrences of each food item in different sizes, seasons and sexes.

Table 2: Variation in \% number of food items ingested by Schilbe mystus in Asejire Lake with respect to size, season and sex

\begin{tabular}{lcccccc}
\hline \multirow{2}{*}{ Food items } & \multicolumn{2}{c}{ Size } & \multicolumn{2}{c}{ Season } & \multicolumn{2}{c}{ Sex } \\
& Small & Large & Dry & Wet & Female & Male \\
\hline Crustaceans & 26.0 & 14.0 & 8.2 & 28.0 & 15.1 & 22.0 \\
Insects & 55.2 & 43.0 & 31.4 & 58.0 & 22.0 & 58.2 \\
Planktons & 18.2 & 26.0 & 55.0 & 15.1 & 62.0 & 12.3 \\
Molluscs & 1.0 & 0.0 & 0.0 & 1.0 & 0.1 & 1.8 \\
Macrophytes & 0.0 & 13.1 & 4.8 & 0.0 & 2.0 & 5.4 \\
Charcoal & 0.5 & 2.1 & 1.5 & 0.0 & 0.0 & 1.8 \\
Unidentified material & 0.0 & 0.8 & 0.1 & 0.0 & 0.0 & 0.1 \\
\hline
\end{tabular}

\section{General diet composition of S. mystus}

Major food items and index of preponderance of S. mystus is presented in Table (3). The food items, discerned from the guts of $S$. mystus, were identified and broadly categorized into crustaceans, insects (Ephemeroptera nymphs, Megaloptera larvae, Hemiptera, Plecoptera, Coleoptera and Odonata), plankton, molluscs, macrophyte, charcoal and unidentified materials. Insects were the most predominant food items accounting for $84.41 \%$ of the total food items. This was followed by crustaceans $(12.59 \%)$ and planktons $(2.97 \%)$. Additionally, the index of preponderance indicated that green charcoal (0.001) and unidentified materials $(0.001 \%)$ were the least food items encountered. The niche breadth (Bi) value of $S$. mystus, as analyzed in the study, is presented in Table (4). Niche breadth value was 2.15 , indicating the presence of broader niches within the area.

Table 3: Diet composition and preponderance index of major food items in the stomach of $S$. mystus from Asejire Lake

\begin{tabular}{lcccc}
\hline Food items & $\begin{array}{c}\text { Index of } \\
\text { Occurrence }\left(\mathbf{O}_{\mathbf{i}}\right) \\
\left(\mathbf{n}_{\mathbf{i}} \times \mathbf{1 0 0} / \sum \mathbf{n}_{\mathbf{i}}\right)\end{array}$ & $\begin{array}{c}\text { Index of } \\
\text { Volume }\left(\mathbf{V}_{\mathbf{i}}\right)\end{array}$ & $\begin{array}{c}\text { Index of } \\
\left(\mathbf{O}_{\mathbf{i}} \times \mathbf{\mathbf { V } _ { \mathbf { i } }}\right.\end{array}$ & $\begin{array}{c}\left.\mathbf{1 0 0} / \sum \mathbf{v}_{\mathbf{i}}\right) \\
\mathbf{p r e p o n d e r a n c} \\
\mathbf{e}\end{array}$ \\
\hline Crustaceans & 15 & 35 & 525 & 12.59 \\
Insects & 64 & 55 & 3520 & 84.41 \\
Plankton & 20 & 6.2 & 124 & 2.97 \\
Mollusc & 0.5 & 1.4 & 0.7 & 0.02 \\
Macrophyte & 0.2 & 1.5 & 0.30 & 0.04 \\
Charcoal & 0.1 & 0.60 & 0.06 & 0.001 \\
Unidentified materials & 0.2 & 0.30 & 0.06 & 0.001 \\
\hline Total & 100 & 100 & 4170.12 & \\
\hline
\end{tabular}


Table 4: Niche breadth of S. mystus in Asejire Lake

\begin{tabular}{cccc}
\hline Food items & Numeric proportion $\left(\mathbf{p}_{\mathbf{i}}\right)$ & $\mathbf{p}_{\mathbf{i}} \mathbf{2}^{\mathbf{2}}$ & $\mathbf{B i}$ \\
\hline Crustaceans & 0.14 & 0.0196 & \\
Insects & 0.64 & 0.4096 & \\
Plankton & 0.19 & 0.0361 & \\
Mollusc & 0.007 & 0.000049 & \\
Macrophyte & 0.02 & 0.0004 & \\
Charcoal & 0.003 & 0.000009 & \\
Unidentified materials & 0.003 & 0.000009 & 2.15
\end{tabular}

\section{DISCUSSION}

\section{Size structure, growth and condition factor of $S$. mystus}

The size distribution $(9.40-29.70 \mathrm{~cm})$ of $S$. mystus, obtained in this study, was comparatively wider than 8.0-21.0 cm and 7.8-21.5 cm reported by Ayoade (2007) in Oyan and Asejire reservoirs, respectively. In addition, Kareem $\boldsymbol{e t}$ al. (2015) reported a wider distribution of 8.30-31.50 cm in Erelu Lake, Nigeria. Kudale-Jadhav and Rathod (2014) asserted that sex ratio of species offers information on sexual viability, segregation and aggregation of sexes according to their feeding, breeding or migratory behavior. The sex ratio in this study showed preponderance of female over male, but did not show any departure from the expected 1:1 rate. In contrast, Komolafe and Arawomo (2011) and Kareem et al. (2015) reported significant female dominant population of S. mystus in Erinle Lake and Erelu Reservoir, respectively. The non-significance of the sex-ratio in this study might be sequel to low sample number.

According to Kareem et al. (2015), the condition factor is an index reflecting interactions between biotic and abiotic factor in the physiological condition of fishes. However, a condition factor that is greater than 1 indicates a generally good condition of the fish, whereas values less than 1, denotes a reverse condition (LeCren, 1951). The condition factor of S. mystus, in this study, is comparable to the observation of Kareem et al. (2015) who reported a similar mean condition factor of $1.071 \pm 0.256$ for $S$. mystus from Erelu Lake. On the contrary, Uneke (2016) recorded a lesser condition factor (0.681) for $S$. mystus from Cross River basin, Nigeria. The regression coefficient (b) value for $S$. mystus was 2.87, with a determination coefficient $\left(\mathrm{R}^{2}\right)$ value of 0.85 . This result suggests that the species shows negative allometry growth; an indication that the fish becomes lighter with an increase in length. However, the correlation coefficients showed strong correlation between the standard length and the body weight of $S$. mystus from Asejire Lake. This result is in consonance with the observations of Kareem et al. (2015) and Abdul et al. (2016) in Erelu Lake and coastal estuary, Ogun Waterside, Oyo, respectively. Contrarily, Ayoade (2011) detected a positive allometry growth (3.348 and 3.2402) in Oyan Lake and Asejire Lake, respectively. 


\section{Diets and feeding habits of $S$. mystus}

Accurate description of the diets and feeding habits of fish species from the wild provided clear understanding of their dietary requirements, which is useful for formulation of artificial diets under culture (Malami et al., 2004). The results of the current study showed variations in diet of $S$. mystus with size, season and sex in Asejire Lake. Similar observations have been reported for S. mystus in Oyan and Asejire reservoirs by Ayoade et al. (2008). The results indicated that the species is a europhagous feeder, able to change their diets according to the availability of different food items as observed by Lowe-McConnell (1977) and Omondi and Ogari (1994). This variation might also be attributed to ontogenetic transformation and life history patterns of the species (Vassilopoulou, 2006). In this study, seven broad categories of food items (crustaceans, insects, planktons, molluscs, macrophytes, charcoal and unidentified materials) were encountered in S. mystus gut. However, the most balanced feeding regime consisted of insects, crustaceans and planktons. This mixed diet composition revealed that the fish is an omnivore. According to Menon and Chacko (1956), fishes fed on filamentous algae, molluscs, worms, and they concluded that fishes whose guts contain sand grains in fair proportions are benthic feeders. Thus, $S$. mystus can be classified as benthic omnivore. This corroborates the earlier findings of Omondi and Ogari (1994) on S. mystus in River Nyando, Kenya. The present findings agree with the work conducted by Ayoade et al. (2008) who reported that insects, plankton and crustacean were the most sorted food item of the species in Oyan and Asejire Lakes, respectively. Furthermore, Omondi and Ogari (1994) found S. mystus from River Nyando, Kenya to be predominantly omnivorous, feeding mainly on chironomids and plant materials. A similar trend was reported by Uneke (2016), who investigated the food, feeding habits and condition factor of the S. mystus from Cross River, Nigeria. The previous author found algae and zooplanktons as major food items of the species. These observations suggest that the availability of food in the habitat is the main factor that determines the feeding habits of S. mystus, and that such species have no food specificity.

Sequel to the presumption, niche breadth values are considered a measure of trophic specialization (Hurlbert, 1978). S. mystus can be considered as specialist. This implies that it consumes a wide range of food items or prey in the Lake. The high niche breadth may be attributed to the reduced competition due to the slightly more diversified nature of the species. A similar increased niche breadth (1.0 to 2.38) in fishes of lake habitats have been documented in the study of Oueda et al. (2008). According to Abdul et al. (2016), high niche breadth enables fishes to switch from one category of food to another in response to fluctuation in their abundance. Moreover, Offem et al. (2008) attributed the ability of the species to utilize many varieties of food effectively to being a trophic generalist.

\section{CONCLUSION}

Schilbe mystus exhibited negative allometry growth with good condition of well-being in Asejire Lake. Dietary analysis revealed that S. mystus is a specialist benthic omnivore feeding mainly on insects, crustaceans and planktons. The high niche breadth indicates a trophic generalist. Therefore, this research provides key information necessary for formulating artificial diet for $S$. mystus under culture environment. 


\section{REFERENCES}

Abdul, W.O.; Omoniyi, I.T.; Agbon, A.O.; Adeosun, F.I.; Olowe, O.S. and Adekoya. E.O. (2016). Food and feeding habits of some fish species in Ogun State Coastal Estuary, Ogun State, Nigeria. Journal of Agricultural Science and Environment, 16(1): 61-74.

Ayoade, A.A. (2007). Age and Growth of the African Butter Catfish, Schilbe mystus (Linnaeus, 1758) in Asejire and Oyan Lakes, South-Western Nigeria. J. of Fisheries and Aquatic Science, 2: 110-119.

Ayoade, A.A. (2011). Length-weight relationship and Diet of African Carp Labeo ogunensis (Boulenger, 1910) in Asejire Lake Southwestern Nigeria. Journal of Fisheries and Aquatic Science, 6: 472-478.

Ayoade, A.A.; Fagade, S. and Adebisi, A. (2008). Diet and dietary habits of the fish Schilbe mystus (Siluriformes: Schilbeidae) in two artificial lakes in Southwestern Nigeria. Revista de Biologia Tropical, 56(4): 1847-1855.

Ayodele, H.A. (1979). The influence of some physico-chemical factors on the composition, abundance and character of zooplankton in some Lakes in Osun River Basin. M.Sc. Thesis, University of Ife, Ile-Ife, Nigeria. 150pp.

Azeroual, A.; Bousso, T.; Getahun, A.; Lalèyè, P.; Moelants, T. and Twongo, T. (2010). Schilbe mystus. The IUCN Red List of Threatened Species. 2010; e.T60385A12347080.

Fagade, S.O. (1978). On the biology of Tilapia guineensis (Dumeril) from Lekki Lagoon. Lagos state, Nigeria. Nigerian Journal of Sciences, 12: 73-85.

FAO. (2018). The State of World Fisheries and Aquaculture: Meeting the Sustainable Development Goals. Fisheries Department, Food and Agriculture Organization of the United Nations, Rome, Italy. 227pp.

Fawole, O.0. (2002). Morphometry and diet of Hyperopisus bebe in the lekki lagoon, Nigeria, Rev. soil Trop., 50(2): 689-694.

FDF. (2011). Fishery Statistics of Nigeria, Federal Department of Fisheries publication, Abuja, Nigeria. 6th Edition. Pp. 21.

Hardy, A.C. (1924). The herring in relation to its marine environment. Part 1. The food and feeding habits of the herring with special reference to the east coast of England. Fish. Invest., London Ser., 2(7): 1-53.

Hurlbert, S.H. (1978). The measurement of niche overlap and some relatives. Ecology, 59: 67-77. https://www.jstor.org/stable/1936632

Hyslop, E.J. (1980). Stomach contents analysis - a review of methods and their application. J. of Fish Biol., 17: 411-429.

Kareem, O.K.; Olanrewaju, A.N. and Alarape, A.A. (2019). Gut contents of Parachanna obscura Gunther 1861, in Eleyele Lake, Southwest Nigeria: A possible indicator of food and feeding habit. SAIRAP (South Asia Institute for Research and Publication) International Conference on Marine Science and Aquaculture (ICMSA - 19), Accra, Ghana. $18^{\text {th }}-19^{\text {th }}$ July, 2019. Pp 37-44. 
Kareem, O.K.; Olanrewaju, A.N. and Orisasona, O. (2015). Length-weight relationship and condition factor of Chrysichythys nigrodigitatus and Schilbe mystus in Erelu Lake, Oyo State, Nigeria. Journal of Fisheries and Livestock Production, 3(3): 150.

Komolafe, O.O. and Arawomo, G.A.O. (2011). Food and diet relationships of Parachanna obscura (Gunther) and Clarias gariepinus (Burchell) in a newly impounded Osinmo reservoir, Ejigbo, Nigeria. Cameroon Journal of Experimental Biology, 7(1): 9-15.

Kpogue, D.N.S.; Mensah, G.A. and Fiogbe, E.D. (2012). Review of biology, ecology and prospect for aquaculture of Parachanna obscura. Reviews in Fish Biology and Fisheries, 23(1): 41-50.

Kudale-Jadhav, S.R. and Rathod, J.L. (2014). Sex ratio of ribbonfish, Lepturacanthus Savala (Cuvier, 1829) from Karwar waters, Karnataka. IOSR Journal of Environmental Science, Toxicology and Food Technology, 8(2): 07-10.

LeCren, E.D. (1951). Length-weight relationship and seasonal cycle in gonad weight and condition in the perch (Perca fluviatilis). Journal of Animal Ecology, 20: 201-219.

Lowe-McConnell, R.H. (1977). Ecology of Fishes in Tropical Waters. Institute of Biology's Studies in Biology, no. 76. London: Arnold, 64pp.

Malami, G.Z.; Ipinjolu, J.K.; Hassan, W.A. and Magawata, I. (2004). Feeding adaptations of ten fish species in River Rima. North Western Nigeria. A paper presented at the 2004 Annual Conference of Zoological society of Nigeria, held at Institute of Development Research, Ahmadu Bello University, Zaria. pp. 1-13.

Malami, G.Z. and Magawata, I. (2010). Analysis of food and feeding habits of catfish (Bagrus bayad, Macropterus (Daget) in River Rima and Goronyo Dam, in Sokoto State, Nigeria. Nigerian Journal of Basic and Applied Science, 18(2): 277-284.

Menon, M.D. and Chacko, P.I. (1956). Food and feeding habits of freshwater fishes of Madras state, India. Proceedings of Indopacific Fish Communication, Section II and III.

Natarajan, A.V. and Jhingran, A.G. (1961). Index of preponderance - a method of grading the food elements in the stomach analysis of fishes. Indian Journal of Fisheries, 8: 54-59.

Offem, B.O.; Akegbejo-Samsons, Y. and Omoniyi, I.T. (2008). Diet, size and reproductive biology of the silver catfish, Chrysichthys nigrodigitatus (Siluriformes: Bagridae) in the Cross River, Nigeria. Revista de Biologia Tropical (International Journal of Tropical Biology), 56: 1785-1799.

Olaosebikan, B.D. and Raji, A. (2013). Field Guide to Nigerian Freshwater Fishes (Revised Edition). National Institute of Freshwater Fisheries Research (NIFFR), New Bussa, Nigeria. Pp. 144.

Omondi, R. and Ogari, J. (1994). Preliminary study on the food and feeding habits of Schilbe mystus (Linn., 1762) in River Nyando. In: Proceedings of the Second EEC Regional Seminar on Recent Trends in Research on Lake Victoria Fisheries, Organized by Kenya Marine and Fisheries Research Institute, Kusumu, Kenya. pp.115-119.

Oso, J.A.; Ayodele, I.A. and Fagbuaro, O. (2006). Food and feeding habits of Oreochromis niloticus (L.) and Sarothrrodon galilaeus (L.) in a tropical reservoir. World Journal of Zoology, 1(2): 118-121.

Oueda, A.; Guenda, W.; Ouattara, A.; Gourene, G.; Hugueny, B. and Kabre, G.B. (2008). Seasonal diet shift of the most important fish species in a Sahelo-Soudanian Reservoir (Burkina Faso). Journal of Fisheries and Aquatic Science, 3: 240-251. 
Reed, W.; Burchad, J.; Hopson, A.J.; Jennes, J. and Yaro, I. (1967). Fish and Fisheries of Northern Nigeria. Gaskiya Corporation, Northern Nigeria, Zaria. 226pp.

Uneke, B.I. (2016). Food, feeding habit and condition factor of Schilbe mystus in mid Cross River flood system, Southeastern Nigeria. American Association for Science and Technology, 3(5): 217-223.

Vassilopoulou, P. (2006). Dietary habits of the deep-sea flatfish, Lepidorhombus boscii in North-Eastern Mediterranean waters. J. Fish Biol., 69: 1202-1220.

Williams, S.B.; Olaosebikan, B.D.; Adeleke, A.O. and Fagbenro, O.A. (2007). Status of African Catfish Farming in Nigeria. In: Proceeding of a workshop on the development of a genetic improvement programme for African catfish, Clarias gariepinus. Ponzoni, R.W. and Nguyen, N.H. (eds.). Accra, Ghana, 5-9 November, 2007. Pp. 49-56.

Zengeya, T. (2016). Schilbe mystus (African butter catfish). Invasive Species Compendium. Wallingford, UK: CAB International. 2014; Retrieved 15 October 2016. 